\title{
De cara a la última instancia José Alberto Hernández en la fotografía contemporánea
}

\author{
Luis Fernando Quirós
}

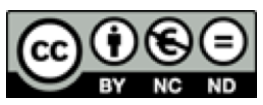

Esta obra está bajo una licencia Creative Commons

Reconocimiento-No comercial-Sin Obra Derivada 



\title{
De cara a la última instancia José Alberto Hernández en la fotografía contemporánea
}

\author{
Luis Fernando Quirós \\ Universidad VÉRITAS. Costa Rica \\ luquiva@gmail.com
}

\begin{abstract}
Resumen
Este ensayo observa el trabajo creativo en fotografía de José Alberto Hernández; analiza su temática la cual focaliza el impacto que tienen las armas de fuego, los convictos en las prisiones y los protocolos carcelarios y de investigación en la obra de arte actual, discurso que conduce la reflexión acerca de la muerte, la violencia y la desesperanza. Asimismo, el escrito esboza una secuencia biográfica intentando evocar las primeras muestras, participaciones en bienales u otros eventos artísticos, históricos, culturales y contextuales que lo formaron y lo catapultaron como artista, hasta contextualizar una de sus recientes exposiciones en el Museo Nacional: "Capturas".

Por último, se analiza el lenguaje e iconografía, recurrencias formales, estilísticas y técnicas en el abordaje a un discurso crítico y una poética que pervive y potencia la discusión sobre el significado del arte en tiempos actuales. Considera, además, referentes en situaciones similares y en otras prácticas artísticas como la literatura, el cine, la pintura y la vida.
\end{abstract}

Palabras clave: fotografía, arte contemporáneo, crítica, ensayo, Historia del Arte, Costa Rica.

\begin{abstract}
This essay looks at the creative work in photography by Jose Alberto Hernandez which analyzes its theme focusing on the impact of firearms, convicts in prisons as well as prison research protocols, through work in contemporary art. His approach leads to reflection about death, violence and hopelessness.

The artist outlines a biographical sequence trying to evoke the first samples of his work that participated
\end{abstract}




\section{Reflexiones}

in biennials or other artistic, historical cultural events that formed and catapulted him as an artist, to contextualize one of his recent exhibitions, "Captures" at the National Museum. In it, he analyzes the language and iconography, formal recurrences, stylistic and technical, in addressing a critical discourse and poetic power, an enduring discussion about meaning of art in modern times. It also considers references in similar situations and in other artistic practices such as literature, film, painting and life.

Keywords: photography, contemporary art, critique, essay, History of Art, Costa Rica. 


\section{Introducción}

La realidad de esta época que nombramos como contemporánea conlleva un acontecer atizado por la violencia y el terror -a nivel macro-, así como los constantes ajustes de cuentas y perversidad en las relaciones interpersonales -a nivel micro-: todas son formas de enfrentamiento social cuyo forcejeo cotidiano acrecienta como nunca la sombra de la desesperanza. Es suficiente atender a las noticias del día a día para cerciorarnos de que entre tantas calamidades está presente una amplia tipología de armas de todo calibre, y que presenciamos tácticas de poder sofisticadas cuyo aguijón nos desestabiliza e incrementa el horror ante el fatídico tránsito hacia la morada final.

\section{Figura 1}

"Mataderos". Serie negra (1998-1999). Fotografía blanco y negro. Ilford film ASA 400 sobre papel fotográfico Ilford y Agfa

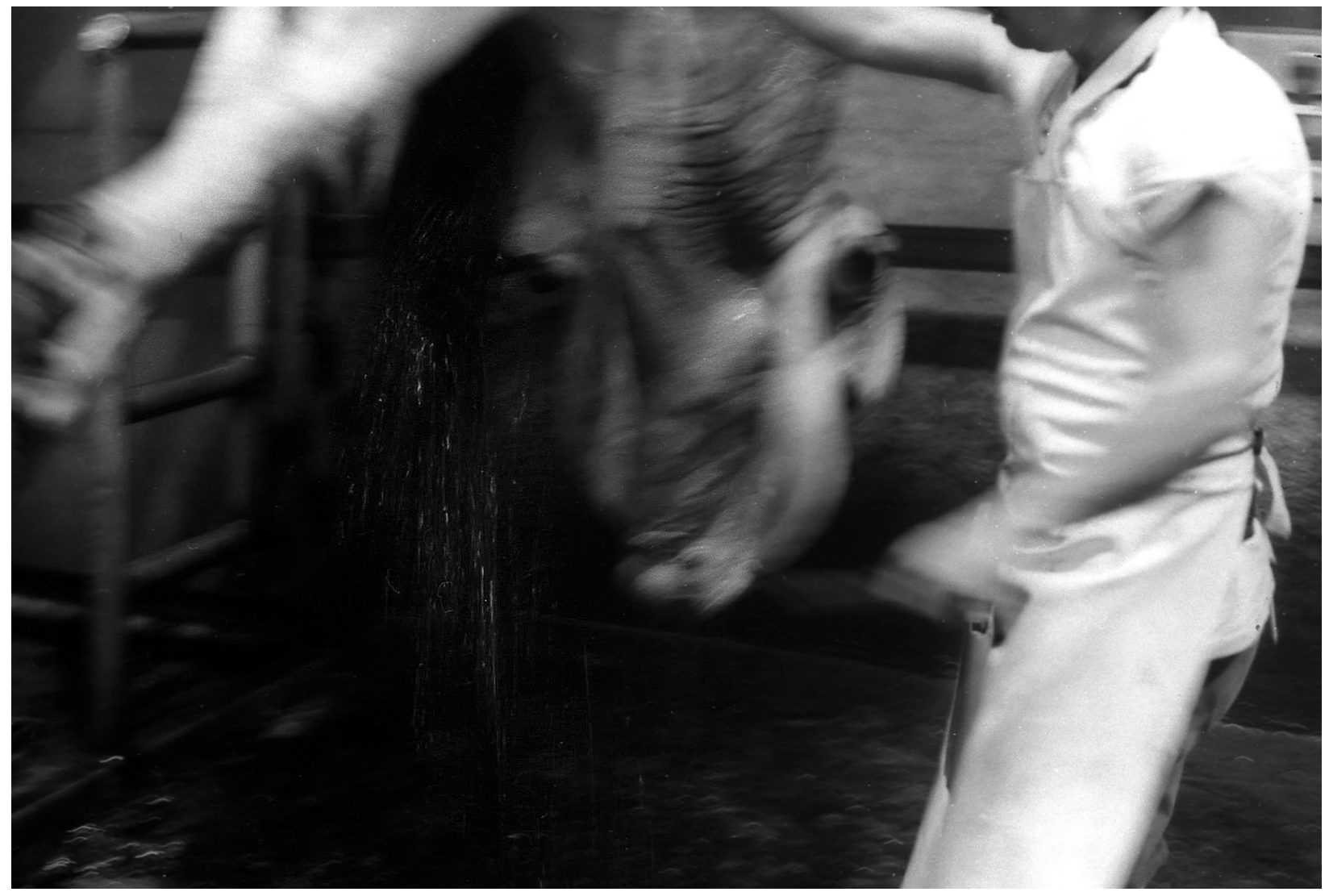

Fuente: Alberto Hernández 


\section{Figura 2}

"Mataderos". Serie Roja (1998-1999). Fotografía a color. Fuji Sensia film ASA 100

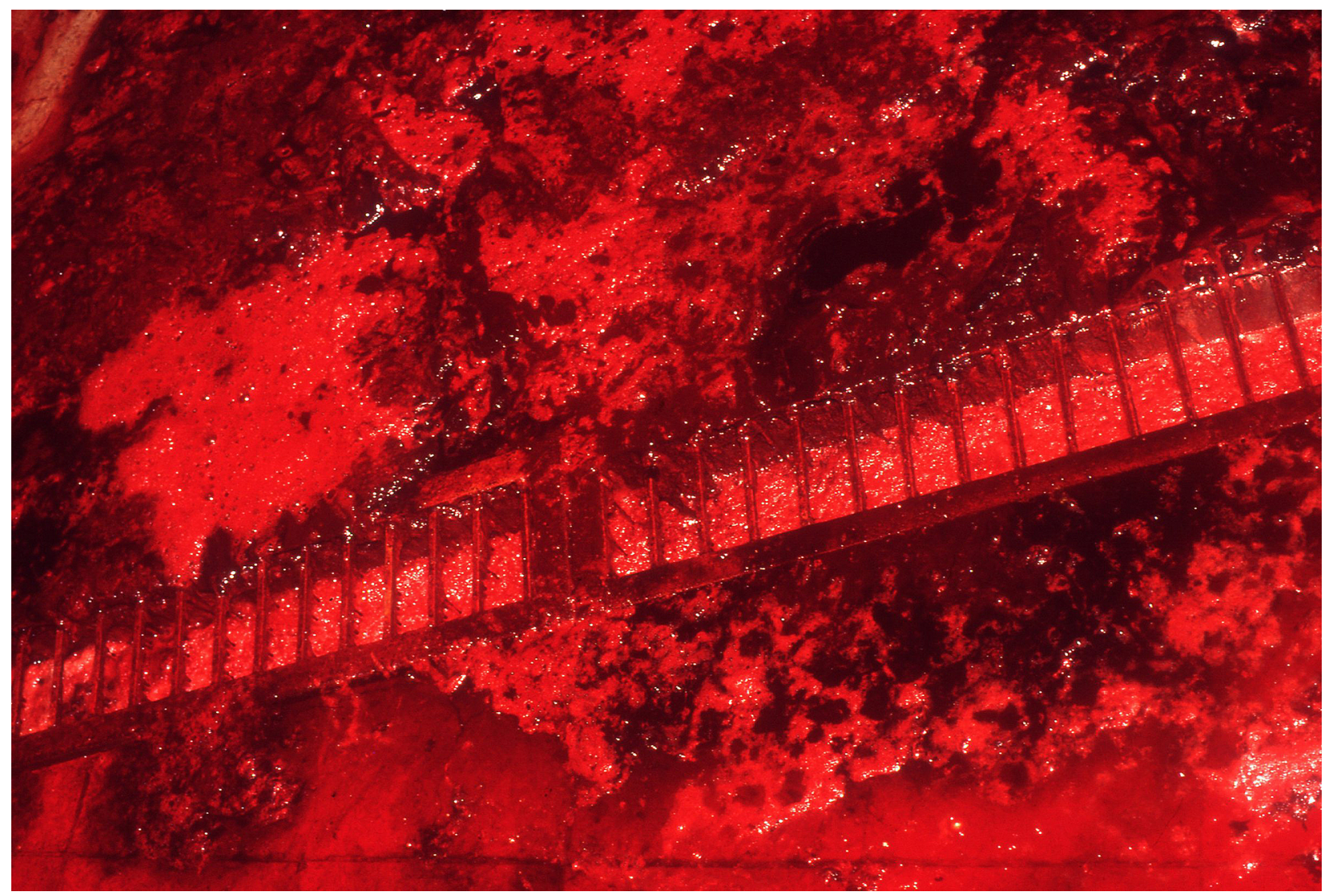

Fuente: Alberto Hernández

\section{El tema de la violencia en la fotografía contemporánea}

El artista fotógrafo José Alberto Hernández (1978), desde finales de la década de 1990, asumió estas problemáticas sociales como abordaje temático de sus búsquedas y principal eje de investigación: "La presencia de la Muerte tras lo fotografiado", Tesis de Investigación (2005) del artista, Universidad de Costa Rica. El significado de la muerte parte de la única condición de estar vivos delante del proyectil, de cara al arma empuñada contra la vida, lo cual provoca reflexión y escudriñamiento de nuestras conductas humanas en estos inicios del tercer milenio.

No obstante, a este artista fotógrafo no solo le interesan las armas y los contextos violentos tan comunes en la actualidad. Este observó la fragilidad humana del individuo 


\section{Figura 3}

"Morgue". Serie Existencia (2002). Fotografía blanco y negro. Ilford film ASA 3200 sobre papel fotográfico Kodak.

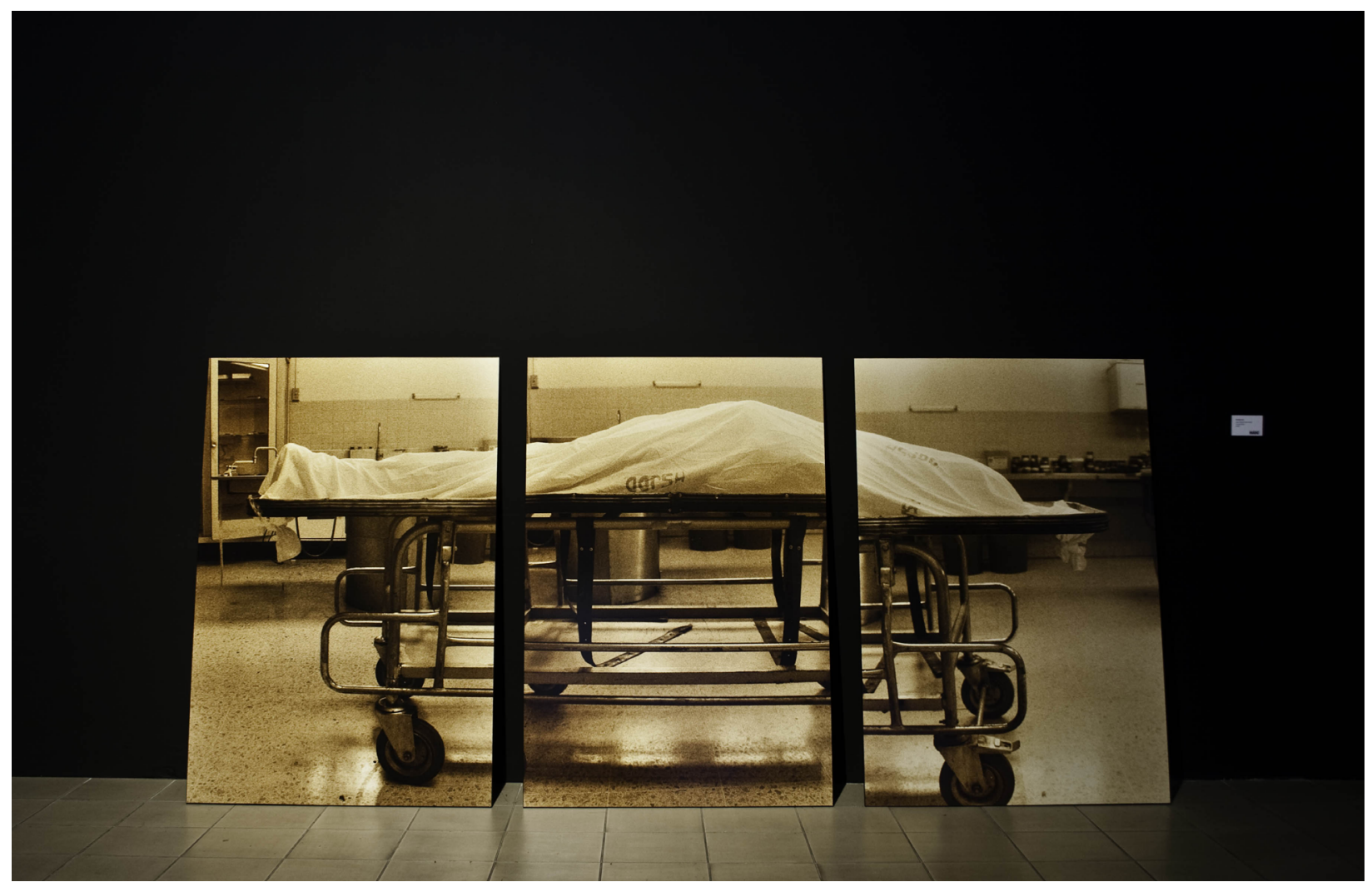

Fuente: Alberto Hernández

-su sujeto de estudio- desde hospitales, salas de operación, laboratorios de disección e incluso, desde la morgue, donde la cualidad humana yace entre despojos e indiferencia. ¡Tremenda percepción la de Hernández, y el arte lo acrecienta para pivotear la más aguda reflexión! Aspecto percibido desde los liminares de su obra con la serie de los "Mataderos" tratada entre 1998-1999.
Intento, con este ensayo, analizar el lenguaje, recurrencias técnicas y de estilo, su pensamiento y propuesta teórica, lo cual fundamenta la discusión y análisis de cómo el arte -en su caso la fotografía- contribuye a tomar posición sobre tan agresivas consecuencias. Se trata de una revisión a su trabajo artístico a través de entrevistas, colecta de información de sus propuestas referentes y el análisis de sus propuestas 


\section{Reflexiones}

\section{Figura 4}

"Morgue". Serie Existencia (2002). Fotografía blanco y negro. Ilford film ASA 3200 sobre papel fotográfico Kodak.

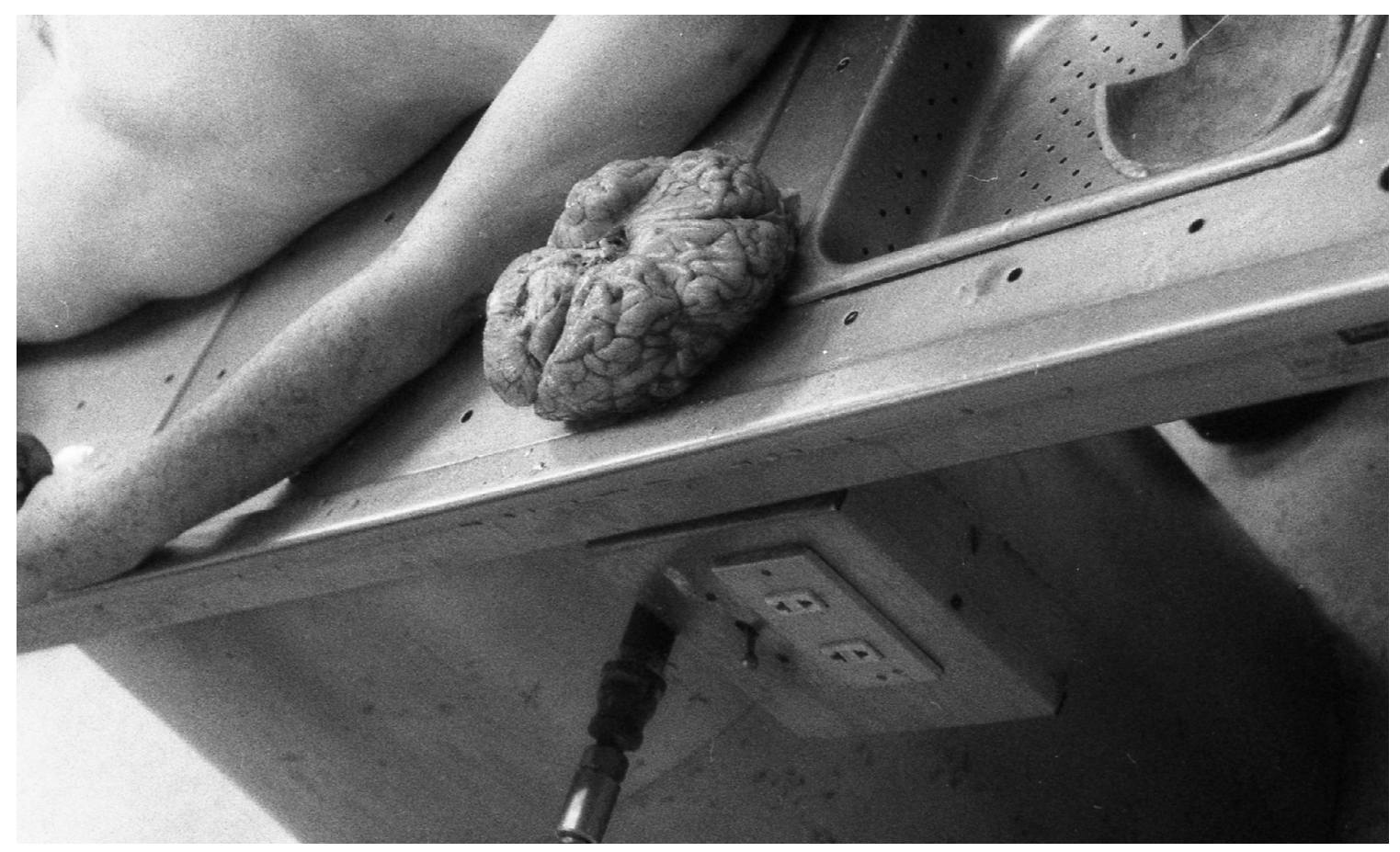

Fuente: Alberto Hernández

fotográficas y focalización de sus exposiciones, hasta arrojar las deducciones necesarias para comprender su visión de la cultura y la manera cómo somos observados por el mundo, en un ámbito donde las comunicaciones trascienden con inmediatez y premura.

\section{De cara al arma}

En su tesis de licenciatura presentada en 2005, Hernández realiza un recorrido por sus series fotográficas en relación con otros referentes y momentos históricos de la fotografía, al tiempo que alude a las armas y a la muerte como principal eje de investigación que dilucida un lenguaje y una focalización conscientizadora que traza en el objeto-sujeto del arte el impacto de estas problemáticas al detonar hoy, como nunca, en la sociedad, el país, la región y el mundo:

Mediante un pequeño esquema o bosquejo referencial puedo deducir que me atraen las relaciones Vida-Muerte / Cuerpo-Objeto; las situaciones de 
vulnerabilidad extrema y la relación con el otro. El tratamiento del cuerpo y la violencia son fenómenos de presencia protagónica en mi trabajo que, sin embargo, fluyen hacia un trasfondo existencial acerca del misterio humano, su abandono, su búsqueda de sentido, su dualidad y fragilidad corporal-espiritual, y que tiene como destino la muerte. (Hernández, 2005)

Habla de un "dúo" actuante, en tanto existe el sujeto que empuña el arma (el agresor $u$ homicida) y al otro lado el agredido, relación que, en ocasiones, también dicha arma se empuña hacia sí mismo (agresor suicida). Se trata de un enfoque que suma a la actual estética de la incertidumbre, cuando las constantes agresiones motivan una toma de conciencia acerca de nuestra fragilidad, o como el mismo artista acota: "vulnerabilidad" delante de tanta matanza en la vida cotidiana y la sociedad misma, estamos inmersos en un día a día aguerrido e intolerante.

Este tema resulta incómodo para gran parte de las personas, ya que lo evaden o le son indiferentes; sin embargo, reflexionar sobre estos males afirma nuestro compromiso histórico de no permanecer callados, tal como lo hace este artista al externar sus divergencias y disensos ante estas contingencias que tanto compungen la vida social y cultural en el mundo entero, tocar un sesgo del arte contemporáneo que podríamos tildar de político.

Tratemos de esculcar entonces algunos significados como el "acto-metáfora" mismo de estar cara a cara con el agresor mediando el objeto aniquilador y el arma, lo cual advierte deslices conductuales que interesa dilucidar desde la teoría del arte y, de alguna manera, también relacionarlo con la diversidad de matices de las personas. Georges Bataille en su libro El Erotismo acota:

Digamos, sin esperar más, que la violencia, así como la muerte que la significa, tienen un sentido doble: de un lado un horror vinculado al apego que nos inspira la vida, nos hace alejarnos; del otro, nos fascina un elemento solemne y a la vez terrorífico que introduce una desavenencia soberana. (Bataille, 2005)

¿Cuál será ese objeto o elemento que introduce -en palabras de Bataille-, una "desavenencia soberana"? ¿Será el sujeto o el arma que dispara la bala, el que a su vez engatilla y desborda el deseo de exponerse a la "excelsa belleza" en la experiencia de la muerte? El poeta austrohúngaro Rainer María von Rilke (1875-1926) lo dijo: "Las obras de arte nacen de quien ha ido hasta el extremo de la experiencia, hasta el punto que ningún humano puede rebasar". Por su parte, el filósofo español Eugenio Trías en "El Artista y la ciudad", citando a Rilke, lo declara de esta otra manera: "La belleza como instancia terrible, ese grado de lo terrible que los humanos podemos soportar" (Trias, 1997).

De ahí que en este ensayo se asocie el acto de morir al imaginario simbólico de Eros y Thánatos. Trías explica al respecto:

Es necesario contactar con la belleza a través del impulso erótico -lo cual implica enajenación, muerte. Pero es preciso 


\section{Reflexiones}

rebasar ese estadio, dejar morir la misma muerte, enajenar la misma enajenación. Y ello en virtud de un resurgir en el que el alma verdaderamente re-nace, siendo ese re-nacer un descenso del estado contemplativo al proceso activo. (Trias, 1997)

¿No es acaso el mismo impulso que llevó a Gustav von Aschenbach en "Muerte en Venecia" de Thomas Mann a dejarse morir ante el deleite erótico de un impulso mundano jamás consumado? ¿No es un acto similar a dar la cara y atravesarse en la ruta del proyectil disparado directo al alma enamorada? Mann lo dijo de esta manera: "Quien contempla la belleza con los ojos se ha conciliado con la muerte" (citado por Trias, 1997).

\section{Formas de la violencia}

En la vida cotidiana y la sociedad se dan formas de agresividad contra la mujer, la juventud, la niñez, los adultos mayores, la familia, las minorías, o con el ser anónimo-del que más nos interesa en la esfera del arte-pues, por lo general, no son agentes noticiosos y no son divulgados; estos se pierden en la memoria furtiva del colectivo social que se esconde detrás de la mampara del día a día, pero las imágenes escarnecen la reflexión; son un tema de actualidad, incluso, la agresión animal y hacia el entorno natural.

Las tácticas del mercado para captar consumidores agreden; también lo hacen las mismas noticias en los medios colectivos de comunicación. Se habla de tensión durante las migraciones de los niños centroamericanos que buscan un mejor norte para su futuro y se disponen de frente al arma. La chispa de una simple mirada puede ser una daga en las relaciones humanas. El forcejeo entre las masas populares y los gobiernos militares centroamericanos del pasado fueron otra forma de violencia. Los "43 de Ayotzinapa" son algo que resuena como incompleto, que deja herida sin suturar, así como otras atrocidades más se cometieron durante las guerras en el resto de Centroamérica de un pasado no tan lejano.

En el escenario mundial cada día se escucha de nuevas matanzas, decapitaciones y destrucción perpetrada por los islamistas de ISIS. Las migraciones en el Mediterráneo en barcas atiborradas de personas que se hunden sin tocar tierra; los migrantes sirios huyen del terrorismo y recién nos conmovió la escena de un niño sirio de cinco años de edad, limpiándose la sangre de la frente como si fuera sudor, empolvado por permanecer debajo de las bombas; también, los migrantes cubanos y africanos que afectan nuestras fronteras y que persiguen una esperanza.

Otro flagelo se presenta en la guerra entre pandillas por el dominio de los territorios de la droga y la corrupción, aún bajo nuestras propias narices. En suma, estamos inmersos en una actualidad intolerante $y$, de alguna manera, el foco de estas propuestas ve hacia los terrenos del arte político, el cual siempre será incómodo para muchos. Sin embargo, es importante reflexionar sobre estos males delante del compromiso histórico del artista de no permanecer callado, sin externar sus 
divergencias o disensos ante las contingencias que tanto compungen la vida social y cultural. Pienso, además, que este contexto tan aguerrido marcó a José Alberto Hernández desde sus inicios; de ahí la idea de la vida y la muerte, las armas y las contingencias sociales tan de naturaleza humana que van dibujándose como una línea sin fin en su trabajo.

\section{Liminares y entorno de crecimiento}

Conocí a José Alberto a finales de los años noventa cuando cursaba las materias intermedias de su formación universitaria en la Escuela de Artes Plásticas, Facultad de Bellas Artes, Universidad de Costa Rica. Evoco su elocuencia y firmeza al defender sus proyectos e ideas. Recuerdo un video de su autoría (dentro de un ejercicio grupal con otros tres estudiantes) que recreó el tema de "Casa Tomada" que nos afectaba anímicamente no solo por los caracteres del relato de Cortázar, sino por la sordidez del entorno en el cual crece la intervención conceptual explorada y motivada por él.

El video fue seleccionado por el curador Rolando Castellón para ser presentado en el importante foro centroamericano de arte contemporáneo “Temas Centrales” (2000), organizado por TEORéTica arte+pensamiento. Hernández, para entonces -y como desarrollaré más adelante-, siendo estudiante, ya se venía incorporando a la escena artística local de su tiempo: había sido seleccionado para la Bienarte (1999), y recibido el premio "Artistas en acción" en 1999, lo que le daría su primera exhibición personal en el Museo de Arte y Diseño Contemporáneo -MADC-, a finales de ese mismo año, con una instalación que tituló Envoltorio Digestivo que consistía en una especie de estómago plástico traslúcido gigante con proyecciones internas y sonidos grabados por él, durante las series de mataderos.

Hernández nació en San José, en julio de 1978, en un entorno social, histórico y cultural costarricense coyuntural cuando, a pesar de la aparente paz, pervivían fuertes tensiones políticas y sociales: la guerra sandinista para conquistar el poder en la República de Nicaragua en 1979 y aquella llamada "paz activa" que ante esos hechos protagonizó el gobierno costarricense, pero que no fue nada activa. Él sería todavía un niño cuando escuchó por las noticias acerca la invasión estadounidense a Panamá (1989) para derrocar al general Noriega y las cañonetas de los artillados norteamericanos apuntaron contra "Chorrillos" hasta desaparecer dicha barriada canalera. Era un adolescente en 1991 cuando se desarrolló la guerra del Golfo Pérsico, y diez años después el ataque a las torres gemelas de World Street Center, en 2001, que marcó el inicio a la guerra contra el terrorismo cargada de imágenes bélicas donde las armas y la muerte fueron el centro de atención.

José es contemporáneo de Guillermo Tovar, Nadia Mendoza, Cinthya Soto, Andrés Carranza, Federico Herrero, Esteban Piedra, Roberto Guerrero, entre otros artistas muy activos en el panorama de la visualidad costarricense actual. En el terreno artístico, 


\section{Reflexiones}

\section{Figura 5}

El interior de la vaca (1999)
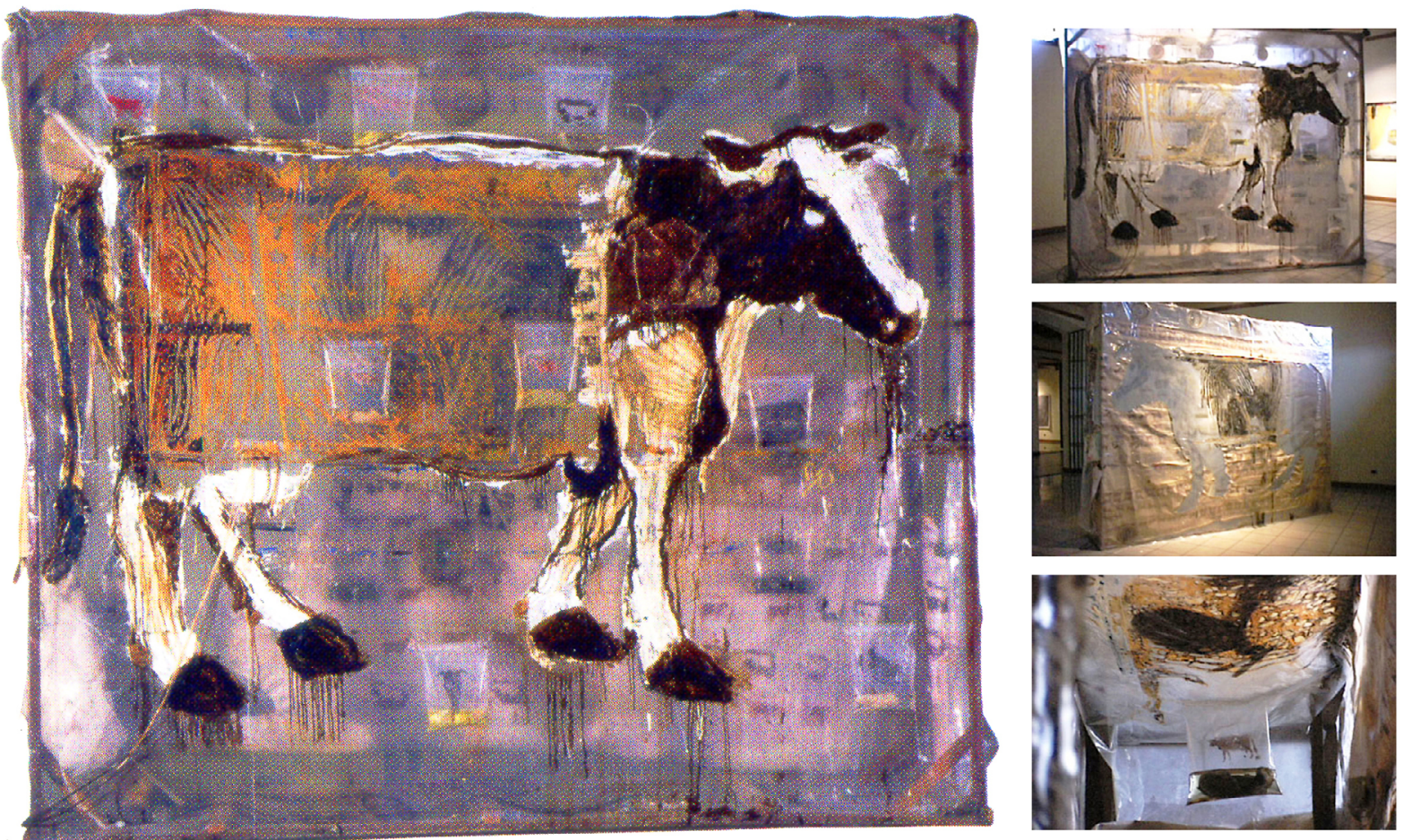

Fuente: Alberto Hernández

durante esos años, trasciende el manejo de los materiales y la manera de expresar la obra artística, como en el Arte Povera, a partir de "materiales pobres" como el uso de arenas, piedras, ramas, troncos, maderas, hojarascas, fragmentos u objetos de metal y tierra. Fueron referentes Mario Merz, Janis Kounellis, el arte matérico de Alberto Burri y Antonio Tapies. Sucedió la irrupción en el escenario internacional del Arte Pop con Robert Rauschemberg, Andy Warhool, Jasper Jonhs, Roy Lichentein, entre otros referentes. Fueron tiempos además de los happenings de Allan Kaprow y el conceptualismo de Joseph Beuys.

Cuando José Alberto inició sus estudios universitarios en la Escuela de Artes Plásticas de la Universidad de Costa Rica, en la primera parte de la década de los años noventa, en donde se daban importantes eventos en el arte local, como la Bienal Lachner y Sáenz, La Bienal de Escultura, los Salones Nacionales de Artes Plásticas organizados por el Museo de Arte Costarricense e inicios de Bienarte, evento que justamente en estos 
meses (agosto-setiembre de 2016) celebró la décima edición con un magno evento en la ciudad de Limón en el Caribe central y en la ciudad capital San José, dirigido por la curadora y crítica cubana Tamara Díaz Bringas. No obstante, en aquellos años de sus comienzos, existía un punto de ebullición que, de alguna manera, marcó sus años juveniles.

Recuerdo su inserción en la plástica nacional cuando presentó, en la segunda Bienarte de 1999, El interior de la vaca. Corresponde además al acceso de Guillermo Tovar en el evento cercano organizado por la Galería Nacional, titulado El artista a través de los objetos (1999), certamen de pintura en el cual Tovar expuso una instalación con distintas materias como pintura, arena, lodo y carne cruda que se iba descomponiendo dentro del contenedor de la obra. En mi perspectiva de esos años presagiaba un arte joven costarricense que tocaría lenguajes execrables como los abominables happenings del austriaco Hermann Nitsch.

\section{El mismo José Alberto comenta al respecto:}

Eso ocurrió en la Bienarte de 1999, cuando el evento aún era solo de pintura. Yo estaba en esa época con mis primeras series de fotos sobre mataderos y siempre me gustaba trabajar desde otras técnicas el tema. Recuerdo de manera especial esa circunstancia, en tanto me costó mucho que me recibieran la propuesta en el concurso, pues tenía el concepto de ser una caja pictórica (angosta) donde la persona se podía meter, y así generar la acción opuesta -el hombre dentro de la res- que al ser traslúcida permitía verse a quien entrara. Por dentro, además, colgué órganos reales de una vaca en formalina. Al ser un objeto transitable, los organizadores argumentaron que ya no era pintura; además, de la pieza salían unas manguerillas plásticas con fluidos que me hicieron tener que introducirlas dentro de la caja porque al dejarlas por fuera me decían sobrepasaba las medidas permitidas. Finalmente, por mi insistencia, la dejaron para evaluación del jurado y fue el crítico de arte Gerardo Mosquera (miembro del jurado) -según me comentaron- quien votó para que El Interior de la vaca formara parte de aquella muestra. Cuando se exhibió, los organizadores colocaron una cinta para que las personas no la atravesaran, pero cada vez que yo tenía oportunidad iba al museo y la quitaba, e incluso sacaba las manguerillas y las dejaba sobre el suelo. (Hernández, 2005)

A mi pregunta ¿qué representan esos años iniciales dentro de tu trayectoria actual?, José Alberto acota:

Esos fueron momentos importantes en mis inicios, pero todo lo que hacía como estudiante de Diseño Gráfico en Bellas Artes en la Universidad de Costa Rica me resultaba tan importante porque era precisamente mi laboratorio de pruebas para salir con propuestas hacia la escena local; cada curso lo tomaba como una oportunidad para probar ideas. Así fue como comencé a desarrollar las primeras series de fotografía y, paralelo a ellas, dedicaba al menos un par de años a investigar y a experimentar conceptualmente 
Figura 6

Los Huevos del gallo (1999)

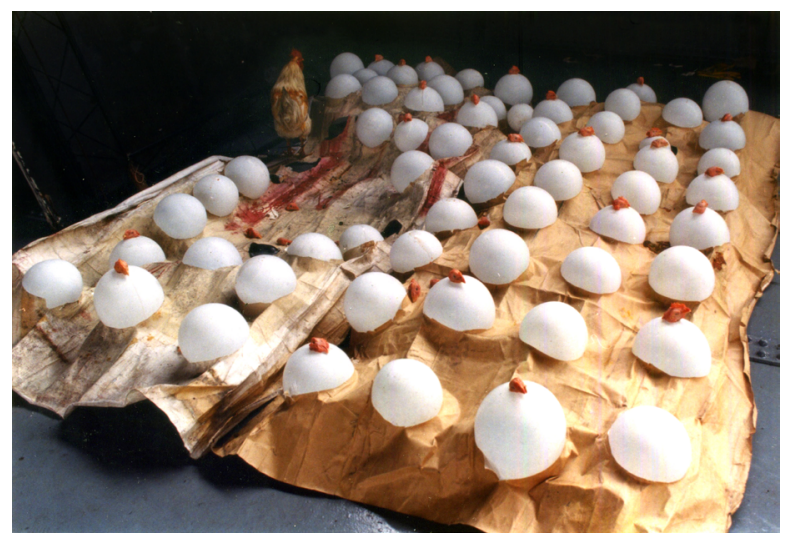

Fuente: Alberto Hernández

desde un tema específico, al tiempo que trataba de integrar a ese tema todos los cursos académicos posibles, para intentar abarcarlo y explorarlo creativamente desde otras técnicas más allá de lo fotográfico. La época universitaria de ese modo fue un eje vital; el lugar y pretexto para realizar todo tipo de ensayos, prueba-error: como estudiante, prefería arriesgar a que un proyecto para un curso me saliera defectuoso por la exploración fallida de la técnica o los materiales, que ir a la segura tan solo por alcanzar una calificación. (Hernández, 2005)

Volviendo a esta visión en retro sobre la labor creativa de Hernández, recuerdo que en 1999 también se dio el concurso de arte en vivo Artistas en acción, donde José Alberto obtuvo el premio con una instalación llamada Los huevos del gallo, la cual consistía en un gran cartón de huevos custodiado por un gallo vivo (sobre cada huevo -globo infladohabía una cabeza de gallina de carnicería). El MADC convocó a tal concurso que tenía como premisa crear una obra in situ, en unas horas, mostrando el proceso de acción a los visitantes. El premio representó la oportunidad para él de hacer una exposición en la

\section{Figura 7}

"Cirugía". Serie Conceptos Vitales (2001). Fotografía a color. Kodak film Gold Max ASA 100 sobre papel fotográfico Kodak

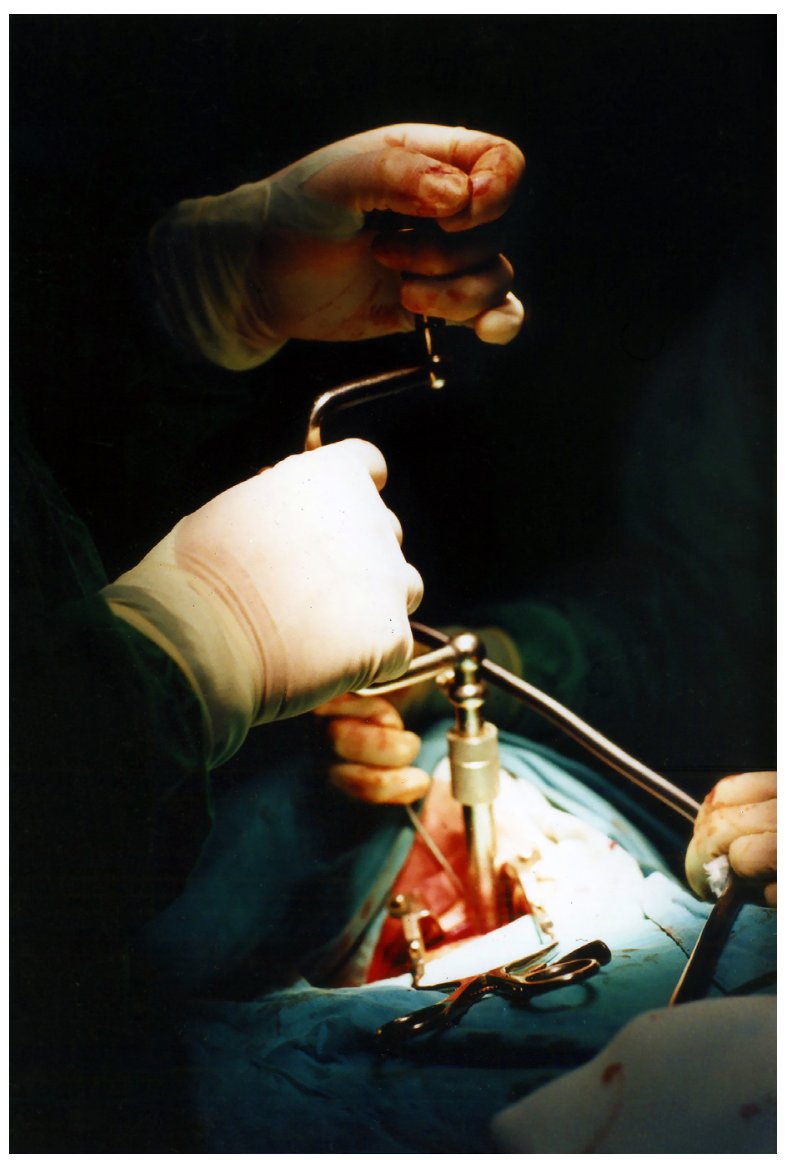

Fuente: Alberto Hernández 
Reflexiones

Figura 8 y 9

Entre 4 paredes (2011). Fotografía a color. Kodak film Gold Max ASA 100 sobre papel fotográfico Kodak
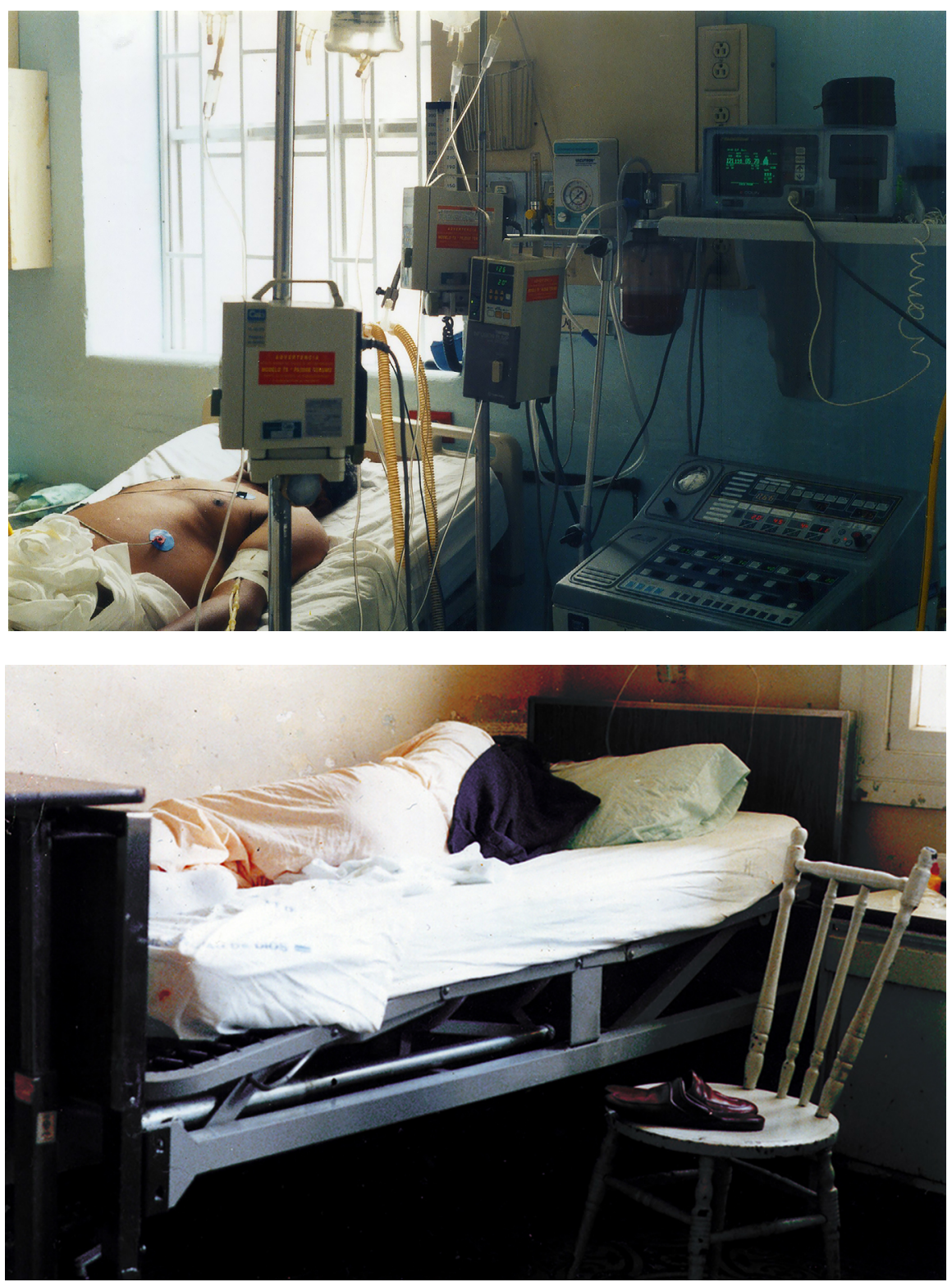

Fuente: Alberto Hernández 


\section{Reflexiones}

Sala 4 de ese museo a finales del mismo año donde completaría con Envoltorio Digestivo, instalación que incluía proyecciones en diapositiva de su serie sobre "Mataderos".

Para Bienarte (2001), en la Galería Nacional, volvió a participar con otra pieza pictórica (transitable) titulada "C.C.S.S." - que incluía además un video- relacionada con el tema sobre el que trabajaba en ese momento, el cual eran los hospitales: "No he sido muy bienalero -explica el artista-, pero las ocasiones en que he participado actué con la premisa de no hacerlo con fotografía, sino usarla como pretexto parar tratar de insertar y mostrar proyectos desde otras técnicas con las que estaba explorando". José Alberto, además, obtendría el segundo premio del Primer Concurso de Videocreación organizado por el MADC en 2002, Inquieta Imagen: Contaminados extensiones de lo Audiovisual, con el video e instalación AUTOPSIS, sobre el

\section{Figura 10}

"Patologías". Serie Ser, tiempo, espacio. (2003) Fotografía a color. Fuji Sensia film ASA 100

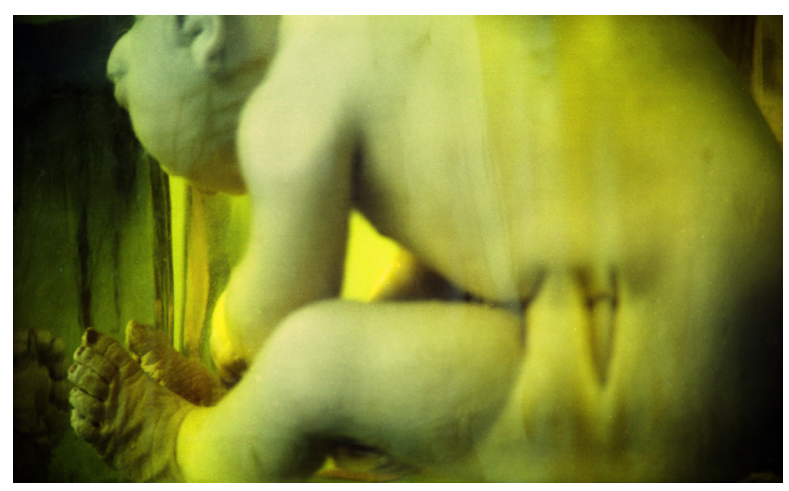

Fuente: Alberto Hernández tema de la morgue. Seguidamente para la I Confrontación en el Arte (2002-2003) en la Galería Nacional, y en in-Tangible (2003) en el MADC, exhibiría imágenes de cuerpos y fragmentos de anatomías humanas suspendidas en formaldehído.

Antes de la muestra Capturas (2016) en el Museo Nacional -comenta Hernándezhe realizado tres exposiciones individuales de fotografía:

Entre 4 paredes (2003) en TEOR/éTica - proyecto expositivo que me llevó a culminar las series de Hospital-el cual consistía básicamente en fotografías de salones y cuerpos en camas hospitalarias. Pongo en el foco la foto en serie porque es mi manera de trabajarla conceptualmente y tener así mis acercamientos para mis reflexiones más existenciales. De igual manera produje la muestra Metodología: Serie Inventario, realizada en el MADC en el año 2007, proceso para culminar en ese momento mis registros de armas decomisadas por el Organismo de Investigación Judicial (OIJ). Dicha muestra consistió en plantear el proyecto de fotografiar armas involucradas en crímenes, el detonante que me motivó a presentar la tesis de Licenciatura en la UCR "La Presencia de la Muerte tras lo fotografiado" (2005) donde recopilo mis series en fotografía en un pequeño ensayo de disertaciones sobre la temática que me inquieta. Seguidamente también en salas del MADC en 2011 realicé el montaje expositivo titulado RIP -Retratos Inconclusos Policiales-, donde trabajé el tema del retrato en la fotografía desde la figura delincuencial. La muestra 


\section{Figura 11 y 12}

"Metodología". Serie Inventario (2005-2007) Fotografía blanco y negro. Ilford film ASA 3200 sobre papel fotográfico Kodak Endura Metallic.

Revólver Hi Standard, Sentinel R-102, Calibre 22 LR, No 11862454. Lesiones mortales / 2 de marzo 1988. Alcardía de Coto Brus / Poder Judicial.

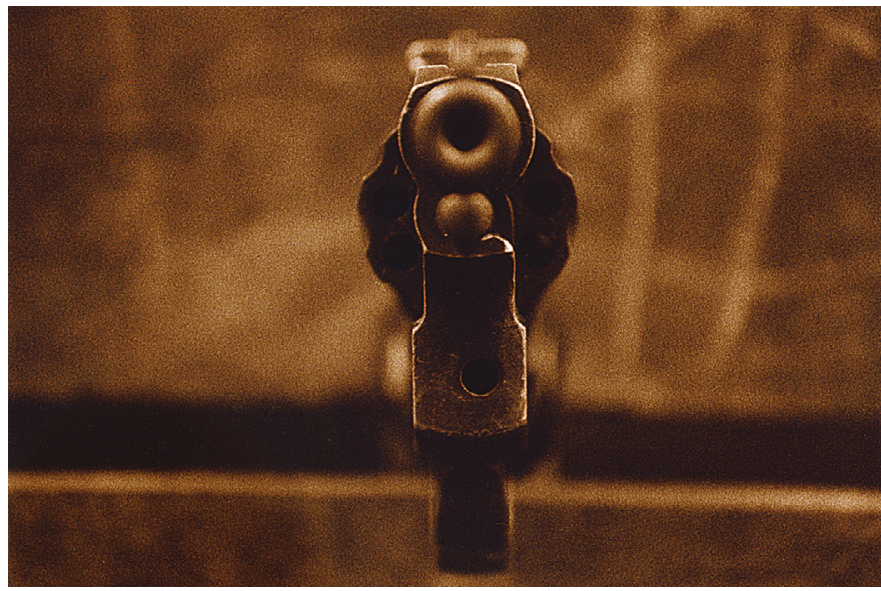

Tríptico. Puñal con empuñadura color negro, $9 \mathrm{~cm}$ de longitud , $2 \mathrm{~cm}$ de ancho y $1 \mathrm{~cm}$ de espesor. Homicidio. 09 de noviembre de 1999 Juzgado penal de San Carlos / Poder Judicial

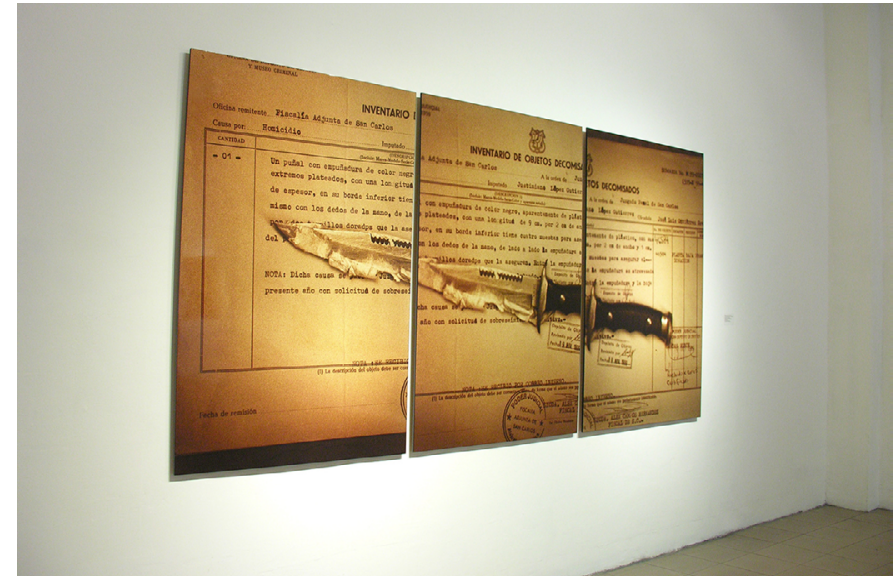

Fuente: Alberto Hernández 


\section{Reflexiones}

Capturas de exhibición reciente en las celdas del antiguo Cuartel de Bellavista, hoy Museo Nacional de Costa Rica, representa una continuidad a ese mismo proceso". (Hernández, 2005)

El teórico y crítico de arte Ernesto Calvo, se refiere a la exposición de José Alberto en el MADC 2007 con la siguiente apreciación:

De este modo, las connotaciones más metafísicas o existenciales que había expuesto este artista en series fotográficas anteriores vinculadas al tema de la muerte, se desplazan aquí de los sujetos víctimas a amenazantes objetos, como especies de metáforas de negadoras y agresivas relaciones de poder, en un rejuego entre Eros y Thánatos que el mismo José Alberto reconoce -en sus reflexiones más íntimas y personales que técnicas o profesionales- como el fin último de su acercamiento al tema de la muerte y su ambigua relación con lo fotográfico. Quizás por eso, tanto en su inventar(io) como en su metodología, este artista explora los casi inasibles lazos entre documentación, fotografía, sujeto y muerte, en un estado pendular que de manera extraña y hasta morbosa- se acerca y aleja constantemente de su incómodo y difícil objeto de estudio. (Calvo, director MADC -2005-2008-, extracto del texto curatorial 2007)

Me parece que es en la propuesta Metodología - Inventario expuesta en salas 3 y 4 del MADC en 2007 -en la cual Hernández define lo que anda buscando-, desnuda lo que puede hacer, lo que posee para impactarnos como observadores de su trabajo en los primeros veinte años de producción artística. Asimismo, este nos muestra sus propias armas, las armas intelectuales con las cuales nos golpea cuando intentamos reflexionar en aquello que él quiere decir, a su manera, con sus recursos, materiales, técnicas, y que emerge desde su interioridad tras horas, días y meses de elaborar conceptualmente cada fotografía, cada propuesta expositiva.

\section{RIP (Retratos Inconclusos Policiales)}

Respecto a esta muestra de José Alberto Hernández, publiqué en uno de mis blogs el siguiente comentario: las Salas 3 y 4 del Museo de Arte y Diseño Contemporáneo se convirtieron en escenario de indagación para la obra creativa de este artista visual costarricense. Aunque contaba con antecedentes de esta muestra -investigué en la web del museo-, me impactó entrar a oscuras, sin la acostumbrada iluminación de un museo de arte; sólo había unas cuantas lámparas con sus cables regados por el piso, de esas que alumbran cuando se cava, se abren fosas, o se escruta entre capas de registros (des)cubiertos en un sitio donde se cometió un crimen.

Tal vez fui uno de los primeros en ingresar a esta muestra -era el momento de la apertura, dentro de un itinerario que marcaba varios puntos en el centro de la ciudad para visitar el circuito de museos capitalinos-, de inmediato, en el túnel de mi memoria se encendieron los recuerdos de cuando años atrás cuando visité el penal abandonado de 
Reflexiones

\section{Figura 13 y 14}

RIP (Retratos Inconclusos Policiales) (2005-2010). Fotografía a color. Kodak film Gold Max ASA 100 sobre papel fotográfico Kodak Endura Metallic

F.A.D. (58) -11 arrestos desde 2005-

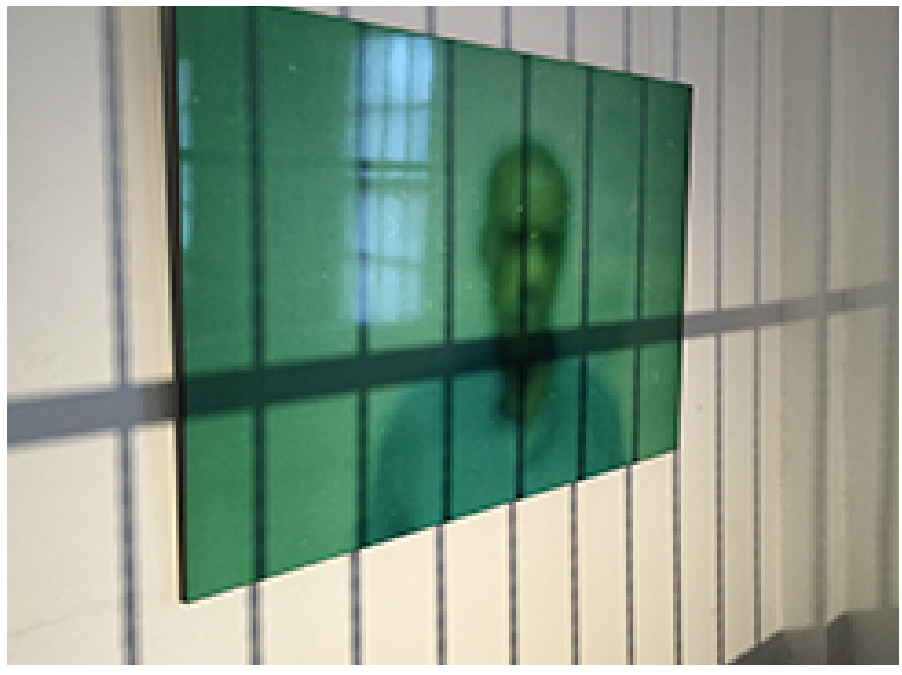

J.C.A. (44) - 13 arrestos desde 2004-

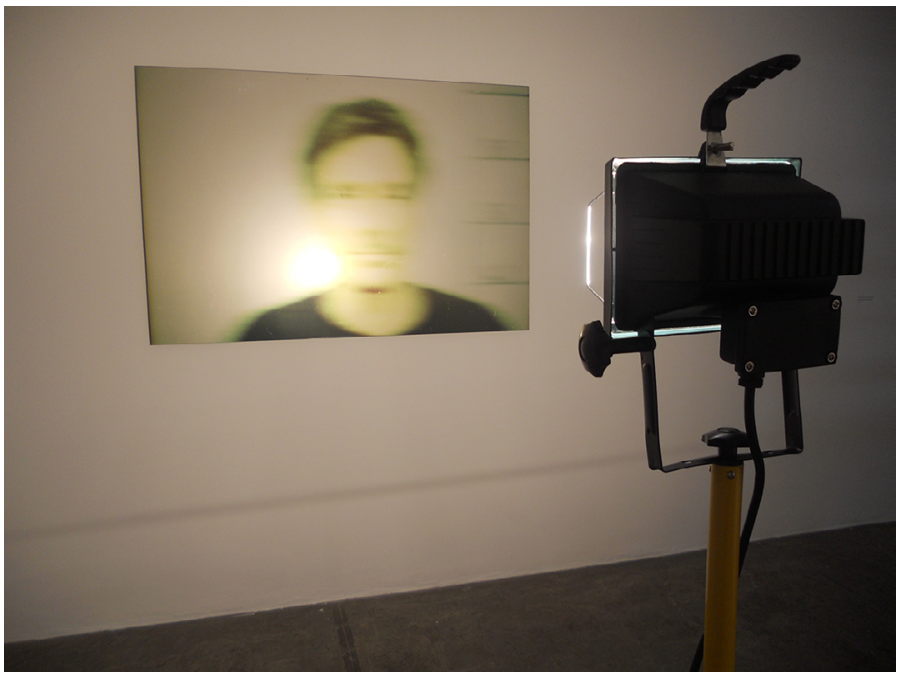

Fuente: Alberto Hernández 
la Isla de San Lucas, en el golfo de Nicoya en el océano Pacífico; u otra inspección a las ruinas de la antigua Penitenciaría Central, antes de que fuera recuperada su añosa edificación para convertirla en el actual Centro Nacional de la Cultura y la Ciencia.

La idea de dejar en manos del visitante el poder manipular las lámparas, encenderlas, apagarlas, desplazarlas, fue una magnífica estrategia suya de intervención del espacio museístico para sumar a la tensión temática tratada, para llevar "luz" hasta aquellos retratos de gran formato, o dar lumbre a las profundas y estrechas oscuridades del crimen, y participar al espectador de la actividad cual si fuera una indagación policial rastreando registros, métricas, huellas, territorialidades, estratificaciones donde (des) cifrar y comprender el enigma de aquellos rostros velados, borrosos, (de)formados por el recurso de la creación de la imagen.

En ese preciso instante se disparó en la "caja" de mis evocaciones e interpretaciones de la obra de arte, aquella otra gran Serie de José Alberto, titulada Inventario, de su muestra Metodología (2007) -Armas decomisadas por el Organismo de Investigación Judicial-, también expuesta en el MADC, para ser parte de esa escena donde sentir el fuego de la propuesta y abrir el flujo de los significados que como vectores cruzan el espacio de las salas.

\section{El artista explica en el catálogo de la exposición:}

Cada (anti)retrato de la serie R.I.P. pertenece a un delincuente reincidente que ha sido capturado por la policía en múltiples ocasiones por varios delitos, pero que finalmente son liberados de manera casi inmediata. Cada uno de ellos es identificado por las siglas de su nombre y la cantidad de detenciones-arrestos por la que ha pasado. (Hernández 2007)

Pero de pronto -vuelvo a la crónica de mi visita a MADC-, me percaté que no estaba escudriñando cárceles visitadas hace ya muchos años, destapando grafitis y anotaciones en sus murallas como si fuera palimpsesto quien revive la acción de cavar para sacar a flote los indicios, sino que me encontraba en la ciudad misma, en el corazón de nuestra capital, en el Centro Nacional de Cultura (sede del MADC), y sentí engatillar en la zona retiniana mi mirada hacia aquellas otras miradas desdibujadas, observándome yo mismo en ellas, en un lapso de confusión existencial, cuando uno no sabe si es víctima, testigo, o cómplice o investigado. Ahí se comprende el poder de la imagen de estimulación emocional hacia el receptor del mensaje, quien se sume en una reflexión acerca de lo visto que lo acrecienta pero que a veces también lo agrede.

Repito, recordé estar en la ciudad, engullido por esa trama de contradicciones, como decía en el siglo pasado el sociólogo alemán Alexander Mitscherlich: "instigadora a la discordia" (Mitscherlich 1978), detonante de la degradación social, de la criminalidad que demuestra astucia, juego salvaje, sin perder la dosis de ambiguo erotismo que poseen sus armas: la bala, cualquiera que sea su calibre, es un símbolo penetrante, erótico si se quiere, pero que hiere y mata. 
Reflexiones

\section{Figura 15 y 16}

Gráfica de Encierro (2011-2016). Taller. Fotografía a color. Fuji ASA 100. Sublimación sobre placas de Aluminio Chromaluxe
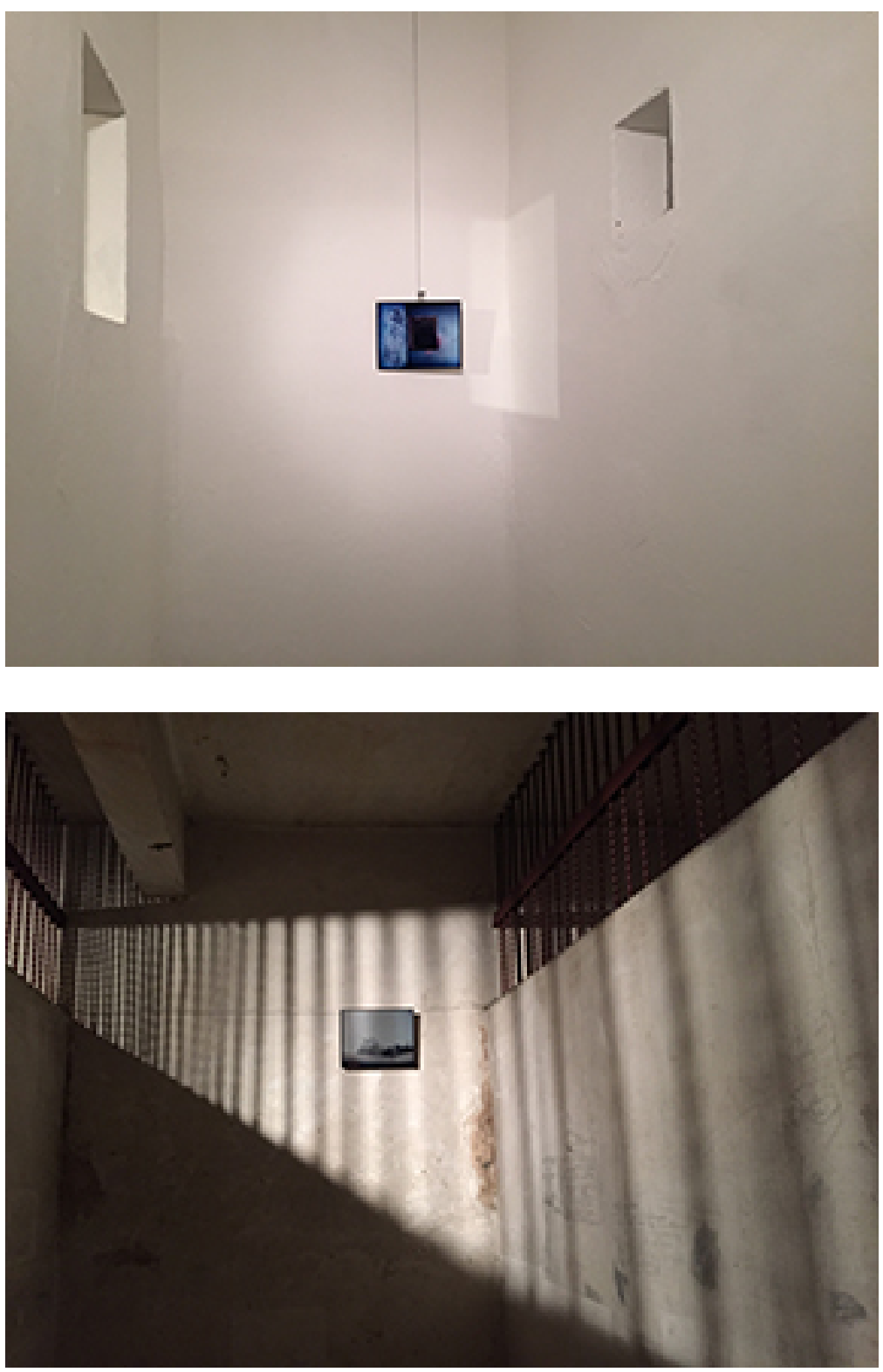

Fuente: Alberto Hernández 


\section{Reflexiones}

Me recuerda aquella visión que cuaja el $p a-$ thos: aquello que provoca el deseo trae la pócima que engulle la vida -la tragedia- hacia la muerte. No puedo tampoco hacer a un lado en mis recuerdos su cartel "ObeliskWDC" expuesto en el Premio Nacional de Diseño Morphogénesis 2009, MADC-, donde Hernández centró una enorme bala blanca, ese objeto exquisitamente minimalista, que se vuelve ícono de los procesos de criminalidad que envuelven a las ciudades doblegadas hoy día por las intenciones perversas del crimen organizado.

Volviendo a la mirada escudriñadora de George Bataille respecto al erotismo que puede activar la sensibilidad del espectador:

El erotismo es uno de los aspectos de la vida interior del hombre. En este punto solemos engañarnos, porque constantemente el hombre busca fuera un objeto del deseo. Ahora bien, ese objeto responde a la interioridad del deseo. (Bataille 2005)

Estos grandes retratos de delincuentes que como roedores serpentean en las venas y arterias de los centros urbanos, cargando su trazado de incertidumbre, están realizadas por un procedimiento técnico también impresionante, en tanto no se trata de impresiones digitales si no de película y papel fotográfico revelado con altísima calidad. José Alberto Hernández vuelve a demostrar el manejo de una técnica y tecnología con rigor, tanto como la fuerza conceptual que detona en su obra desde sus inicios, que fluye entre la porosidad que bordea la vida y la muerte.

\section{(En)torno a una "captura"}

El Museo de Arte y Diseño Contemporáneo (MADC) y el Museo Nacional de Costa Rica (MNCR) mancomunaron esfuerzos para abrir entre mayo y agosto 2016 una muestra de este autor en lo que fueran los calabozos del antiguo "Cuartel de Bella Vista", marco que agrega sentido al exponer sus dramáticas fotografías. Curada por Adriana Collado y expuesta del 26 de mayo al 21 de agosto 2016.

\section{Enigmático entorno}

Las vibraciones propias del espacio expositivo puede que carguen de interés a cada signo o imagen catapultada para imbricar en el discurso central: la existencia de una forma de belleza advertida quizás en ciertos grados del dolor, persistentes en vivencias traumáticas o en estados de la inconciencia del ser activo en la temática fotográfica. Es ahí que lo expuesto es advertido en ese grado de aproximación a lo bello que pueden tener esos grandes íconos de armas o las mismas balas o proyectiles a veces dirigidos en contra de nuestra propia humanidad. Aparecen fotos de revólveres, rifles, balas, casquillos, detalles de los mecanismos y aparataje estudiado por la balística que fueron expuestos en 2007 en el MADC con el título Metodología: Serie Inventario. Se exhiben, además, en esos antiguos espacios de reclusión algunos retratos de la serie $R I P, R e-$ tratos Inconclusos Policiales (2005-2010), se trata de convictos que quizás aún purgan en prisión y lo demuestran sus rostros difusos, marcados por una "deformidad" intencionada por parte del artista para no explicitar la 
identidad del sujeto ya sentenciado o en caso de estudio policial; también aparecen algunos protocolos de archivo e indicios útiles para el registro o administración penal y judicial.

Este encuadre conforma el "texto" principal de lo expuesto, pero se disfruta de igual manera la existencia de un "contra-texto", con unas fotografías de pequeño formato e impresas en un material distinto, quizás metálico, que a veces nos sacan de la lectura principal al estar dispuestas en sitios inesperados -o muy abajo o muy arriba de las paredes-, provenientes de una acción del artista titulada "Gráfica de Encierro" (2011-2016) realizada en un penal, cuando él dio a un grupo de reclusos una cámara compacta (con película incorporada) para que capturaran su propio entorno, la cárcel física tangible desde dentro, la que ellos perciben como paisaje del día a día. Intenso e interesante estudio que requiere otro carácter de la mirada, en ese caso, la sociológica.

Definitivamente cuando un individuo creativo, sensible y obstinado por perseguir sus propósitos - como es el caso de José Alberto Hernández-, ha puesto tanto pensamiento en un proyecto, y se suma el de la curadora Collado, dan sentido a un estado insigh, clarividencia profunda, vivencialidad donde todo amarra o (con)cuerda, y al fluir contribuye sustancialmente a "amarrar" la lectura e investigación acerca de la muestra.

Ernesto Calvo en un artículo publicado por "Áncora" de La Nación, comenta en esta ocasión lo siguiente:
El espacio donde ha puesto a interactuar estas tres series fotográficas no puede ser más propicio, no solo desde el aspecto museográfico, sino también por sus connotaciones metafóricas: los calabozos del antiguo Cuartel Bellavista (actual sede del Museo Nacional), donde resuenan aún, entre su laberíntico recorrido, sus desdibujados grafitis, sus habitaciones diminutas y su humedad, algunos de los lejanos ecos de lo que se vivió en un pasado. Quizá por eso las fotos que interactúan en ese entorno antiguamente carcelario, ganan en intensidades y lecturas, las cuales son imposibles de lograr en los espacios más bien asépticos de un museo convencional.

Por otro lado, tanto en Inventario como en RIP - Retratos inconclusos policiales -, como en Gráfica de encierro , hay una engañosa condición de lo "documental" dentro de la fotografía. Archivos judiciales, armas decomisadas, retratos policiales y fotos realizadas por los reclusos son, de alguna manera, "apropiadas" por el investigador-fotógrafo, que las interviene y transforma: desde los detalles de las actas y los fragmentos de las armas, a la difuminación de los rostros retratados o las pequeñas imágenes de reclusos. ( $\mathrm{La}$ Nación, Calvo, 2016)

\section{Capturas de la memoria}

Antes de desarrollar los siguientes argumentos, me detengo a explicar que intento contextualizar el significado mismo de ser un presidiario en esta sociedad, advertir sus 


\section{Reflexiones}

congojas, tensiones, dolor que no está nada ausente en la vida cuando se es privado de libertad, y habrá tantas memorias como lecturas se hagan de dicho trance visto a través del prisma del arte contemporáneo. Como intérprete de lo expuesto al tratar de caminar por la exhibición, me vienen a la mente situaciones vividas, lecturas realizadas, e incluso percepciones de algún film que me impactó y me ayudan a interpretar, a observar, a analizar, a pensar... Por lo que retornó a la memoria de una señora -cuando yo era estudiante en la ciudad de Roma en los años ochenta, y el estudio del maestro que frecuentaba se ubicaba al lado de los muros de Regina Coeli, temible reclusorio en el Trastevere, allá en la ciudad eterna-, una mujer, quizás madre o esposa, llegaba en las mañanas a la hora que salían los reclusos a recibir el sol, al otro lado de aquellas altas murallas, y desgalillaba al aire mensajes que quizás el destinatario no recibiría o quizás sí. En esa compleja percepción comprendí el significado de la prisión, donde se pueden escuchar muchas voces pero en el fondo nadie las escucha, puede haber muchos rostros pero nadie los ve, la espera desespera, pues los cambios se cuentan no en minutos u horas como en nuestra vida diaria, sino en años, donde la vivencia de lo temporal es muy distinta, sinónimo de incertidumbre, indiferencia, trágica negación.

Recordé también mis tiempos juveniles cuando leí aquella novela de José León Sánchez, La isla de los hombres solos, vivencia espeluznante ocurrida en el presidio de San Lucas, que un día de tantos visité, y al posar la mirada entre los barrotes, los grafitis y el repaso de lo leído, comprendí realmente lo inefable del suplicio.

Mientras caminaba por las salas de la muestra, en la zona de antiguos calabozos, recordé otra lectura, la de Oscar Wilde con su Epístola: "In Carcere et Vinculis" (De Profundis), y en cada pieza de la muestra machacaba los signos de la desesperanza cuántos relatos de tortura, de desazón y espasmo; precisamente recordé la última frase con que concluye esta tremenda carta escrita por Wilde en sus años de reclusión, el estado más bajo en que puede caer un individuo: "Quizás me fue dado enseñarte algo mucho más maravilloso: el sentido del dolor - y su belleza”.

\section{¿Belleza del dolor?}

Esta percepción es tremenda y ¿acaso, no es central en el discurso de esta muestra? Pareciera enfermizo considerar "la belleza del dolor" pero en el fondo es un concepto "tiritante" -comprendido solo por quienes por su sensibilidad y atención a lo observado, encuentran acceso al estado de insigh ya comentado. José Alberto cual "catador de belleza" la encuentra donde sea, en una pared grafiteada, en la camilla de un hospital o entre sus sábanas, una bala, un revolver..., recrea esos ardores donde persiste el signo del dolor entremezclado con lo sublime de lo bello y, hasta incluso, con el deleite de lo sensual.

Pero mis percepciones de "Capturas" no terminaron ahí; caminé por los vericuetos y subespacios donde a veces se esconden las 
palabras y frases, donde se decodifican los mensajes que no están a simple vista: Siempre he afirmado que caminar es sinónimo de pensar, de escudriñar, de asumir los significados.

Recordé otra lectura más, la de Urbanoscopio (1997) del célebre escritor nacional Fernando Contreras Castro, donde en una de sus narraciones refiere a cómo eliminar las cárceles, en un experimento con un grupo de reclusos a quienes a cambio de quedar libres les fue implantado un dispositivo, para que el privado de libertad observara de por vida unos barrotes que le recordaran su condición.

Tremenda quimera:

"Y salieron a la calle después de la convalecencia, con sus anteojos a rayas, se despidieron, se dispersaron y fueron a donde les dio la gana mirando al mundo desde las celdas diminutas de sus ojos. A donde quiera que dirigían la vista, ahí estaban perennes las ventanas de barrotes... siempre las rejas proyectadas sobre la superficie del mar, sobre la piel de las mujeres desnudas, entre sus ojos y los ojos de sus madres, entre los ojos y los ojos de sus hijos, entre los ojos y los ojos del mundo". (Contreras Castro, 1997)

Termina esta narración de Contreras Castro con lo siguiente: "Solo sobrevivieron los dos que vaciaron los ojos".

Detallo el argumento de este cuento que capturó mi sensibilidad y los ojos de la memoria, pues una de las piezas RIP -Retratos Policiales Inconclusos-, expuesta en una zona de los calabozos del antiguo cuartel, a la fotografía le caen unas sombras de barrotes que provienen de otra estancia pero que indirectamente la afecta y propaga ese alto signo de incertidumbre.

Es más, en esa revisión al trabajo creativo de José Alberto Hernández recordé otro acto que no quiero omitir; se trata de la experiencia de la artista cubana Tania Brughera al plantear precisamente finalizando el año 2014 El Susurro de Tatlin \#6 en Plaza de la Revolución de La Habana, por lo cual fue detenida y confiscados sus documentos, en otro de los confines de la disidencia, y la connotación de la cárcel política por la cual también urge reflexionar.

No quiero terminar esta relación a la literatura que me ha impactado como formas de reclusión sin comentar la novela del japonés Kobo Ábé El Rostro Ajeno de 1994: ¿puede una máscara ser un signo de reclusión como el tratado por este autor? La obra relata la vida de un científico que sufre un accidente en el laboratorio donde se vuela su cara, y desde ese preciso momento inicia una investigación autorreferencial para procurar hacerse una máscara propia, para lo cual investiga su misma piel, las facciones anatómicas de su rostro, todo lo referente a devolverse su identidad y personalidad. Quizás lo logra e incluso intenta el robo de otras personalidades sin resultados, pero cuando obtiene el objeto de su deseo, esa máscara lo traiciona y se vuelve reclusorio en tanto invade su comportamiento en la sociedad y comienza el litigio por asumir su identidad.

No están lejos de este tratamiento algunos libros como aquel famoso drama de Tennessee 


\section{Reflexiones}

Williams De repente, un verano, llevado al cine por Mankiewicz con la dramática actuación de Elizabeth Taylor, Montgomery Clift y Katharine Hepburn, esta última es quien representa la madre de "Sebastián", el personaje ausente pero sobre el cual versa el conflicto de esta obra. O la misma Muerte en Venecia de Thomas Mann -ya comentada en este texto-, puesta en la gran pantalla por el célebre Lucchino Visconti, ambas joyas de la cinematografía.

Sin hablar de otro monstruo del cine, el italiano Pier Paolo Pasolini, quien basado en el texto del Marqúes de Sade montó Los 120 días de Sodoma, tétrica detonación de sexo, violencia, sadismo, armas y muerte. Y, para terminar con esta ojeada a la literatura y al cine, como no mencionar el filme La Pele, de Liliana Cavani, sobre la convulsa entrada de las tropas norteamericanas a Italia que puso fin a la segunda Guerra Mundial, en una trama de sangre y dolor en la historia del cine moderno.

\section{Revisión a la historia del arte}

¿Qué intento lograr con este tratamiento para hablar del arte de José Alberto? Intento una reflexión más allá del acostumbrado comentario, que me lleva incluso a buscar argumentos ya observados en la historia del arte, y dar una ojeada, aunque breve, a la intensidad del relato de la muerte y la violencia en algunas piezas muy representativas de ese carácter del arte.

Esta aproximación al trabajo artístico de José Alberto, me intriga a buscar no solo formas de violencia expresadas en pinturas de guerras, fusilamientos, asesinatos, sino también la enfermedad que doblega al ser humano, o hasta la misma crucifixión que conduce a la cripta, como la "Lamentación sobre Cristo" pintada entre 1470 y 1480 por Andrea Mantegna (1431-1506), famoso no solo por el dominio del escorzo o perspectiva y realismo logrado en aquellos tiempos del Renacimiento italiano, sino por la atmósfera fría de la cripta que embarga al Cristo y su impacto psicológico sobre el espectador que visita la Pinacoteca Brera de Milán.

"Judit y Holofernes" es uno de los episodios bíblicos violentos representados en la historia pintura italiana, entre los cuales se cuenta el pintado por Caravaggio, que afecta al espectador con un clima psicológico, crudo, dramático, tanto como la pintado por Artemisia Gentileschi "Judit decapitando a Holofernes" conservado en la Galería Uffizi de Florencia.

Es memorable, entre otras telas pintadas con temática similar, la de Francisco de Goya y Lucientes sobre los Fusilamientos del 2 de mayo ocurridos en Madrid en 1808, pintada en 1814, entre otras de sus pinturas que agrega expectación y crudeza.

A inicios del siglo XX, impacta por su crudeza "La Muerte de Marat", 1907, pintada por Edvard Munch, tétrica y sangrienta en tanto es representada una escena sexual más cercana a la actual representación de la violencia. O la "Figura con carne" de 1954 pintada por Francis Bacon, evocando a "Inocencio X" a su vez pintado por Velázquez en 1650. 


\section{Conclusión: Cárceles interiores}

Las fotografías impresas con técnicas bastante particulares, siguiendo procedimientos muy rigurosos para obtener los resultados característicos del trabajo de este autor costarricense, finamente retablados, hablan mucho de sus rigores como diseñador quien sabe de control de calidad, racionalidad del proceso y sobre todo el manejo de la imagen. Para algunas personas es demasiado, aduciendo que la imaginación del observador se ve constreñida al seguir los vericuetos de la técnica y el control de los acabados; pero no son reveses sino fortalezas creativas de un individuo trabajador, quien piensa largamente en lo que hace, quien medita hasta el mínimo movimiento que pueda afectar la lectura de sus intensas obras de arte de una realidad combativa y crítica. Estos son logros de quien investiga, de quien se lee a sí mismo para agregar interés marcado por su experiencia machacada por la astucia creativa, y la constancia.

Ya para concluir con este acercamiento a la muestra Capturas de José Alberto Hernández en el Museo Nacional, quisiera agregar que algunas personas llevan una cárcel dentro, aunque sean libres y anden por las calles - pero no hablo de la del experimento relatado en Urbanoscopio del autor Contreras Castro-, hablo de la prisión de la vergüenza, la cárcel del miedo, o del ser convicto por la angustia de no reconocer una verdad: hablo del patíbulo psicológico que con tanta crueldad trató Katharine Hepburn en la pieza teatral de Tennessee Williams ya comentada, o la "picota" que revela el signo de la belleza que no apartó de sus labios Von Auschemberg en Muerte en

\section{Venecia.}

También, muchos acceden a experiencias similares por cuestiones religiosas como las producidas por el terrorismo y la guerra, o para provocar una reflexión acerca de las virtudes de la vida en libertad. No queda al margen las connotaciones políticas que tanto repudio tienen aún a estas alturas de la civilización: la bala, el orificio del revolver dirigido contra nuestra humanidad dicho en el papel fotográfico, la pulidísima impresión, y el ojo sagaz y sincero de José Alberto Hernández.

\section{Referencias}

Bataille, G. (2005). El Erotsimo. Barcelona: Tusquets Editores.

Calvo, E. (2016). Capturas Documental Inasible. La Nación, Áncora. Recuperado de http://www.nacion.com/ocio/artes/ Exposicion-fotografias-Capturas-docu

Hernández, J. A. (2005). La Presencia de la Muerte tras lo fotografiado. Universidad de Costa Rica, Memoria para optar por el grado de Licenciatura en Artes PlásticasCon énfasis en Diseño Gráfico. Recuperado de http://www.josealberto-espaciosvacios.com

Trías, E. (1997). El Artista y la Ciudad. Barcelona: Anagrama.mental-inasible_0_1566443371.html)

Quirós, L.F. (s.f.). Retratos Inconclusos Policiales. Recuperado de http://www. experimenta.es/blog/luis-fernando-quiros/\%E2\%80\%9Cretratos-inconclusos-policiales\%E2\%80\%9D-de-jose-alberto-hernandez-2875/) 


\section{Reflexiones}

212 ESCENA . Revista de las artes, 2016, Volumen 76, Número 1, págs. 185- ISSN 1409-2522 